\title{
R-(-)-Gossypol Acetic Acid
}

National Cancer Institute

\section{Source}

National Cancer Institute. R-(-)-Gossypol Acetic Acid. NCI Thesaurus. Code C78348.

The orally bioavailable solvate of the R-(-) enantiomer of gossypol and acetic acid with potential antineoplastic activity. As a BH3 mimetic, R-(-)-gossypol binds to the hydrophobic surface binding groove $\mathrm{BH} 3$ of the anti-apoptotic proteins $\mathrm{BCl}-2$ and $\mathrm{Bcl}-\mathrm{xL}$, blocking their heterodimerization with pro-apoptotic members of the $\mathrm{Bcl}-2$ family of proteins such as Bad, Bid, and Bim; this may result in the inhibition of tumor cell proliferation and the induction of tumor cell apoptosis. Racemic gossypol is a polyphenolic compound isolated from cottonseed. 